\title{
Personal and Work-Life Perceptions of Sri Lankan Prison Correctional and Rehabilitation Officers
}

\author{
Nimali Wijegoonewardene ${ }^{a, b,{ }^{*}}$ and Janaki Vidanapathirana ${ }^{a, c}$ \\ a National STD/ AIDS Control Programme, Ministry of Health, Colombo 10, Sri Lanka \\ b University of Lincoln, Lincoln LN6 7TS, United Kingdom \\ c National Cancer Control Programme, Colombo 00500, Sri Lanka \\ *Corresponding author Ph: +447549266904; Email: nimali7@hotmail.com \\ DOI: https://doi.org/10.34256/ajir2131 \\ Received: 15-06-2021; Revised: 05-07-2021; Accepted: 05-07-2021 Published: 08-07-2021
}

Abstract: Working as a prison officer is known to be stressful and demanding. This paper aims to assess the personal and work-related perceptions of Sri Lankan prison officers working in close contact with inmates, and it is part of a larger study carried out in 2017. A descriptive cross-sectional study was conducted in 2017 among 1803 'ground level' prison officers across the country, consisting of 1683 prison guards and 120 prison rehabilitation officers. Their perceptions related to personal-life and work-life were assessed using a self-administered questionnaire. Percentages were calculated in the analysis. The majority of the sample were between $25-54$ years $(85.9 \%)$, and male $(88 \%)$. Out of the participants, $232(12.9 \%)$ felt their family-life was adversely affecting work-life, while $412(22.9 \%)$ thought their work-life was adversely affecting family-life. $102(5.7 \%)$ felt they couldn't take leave even for an urgent need. While $1369(75.9 \%)$ always had a clear idea about their duty, $338(18.7 \%)$ felt there were no career prospects in the job. $398(22.1 \%)$ felt they were overloaded with work. Around one fourth of the participants felt job insecurity most of the time. Regarding work relationships, 292 (16.2\%), 65 (3.6\%) and 167 (9.3\%) thought their relationship was excellent with colleagues, inmates and superiors, respectively. Around sixty percent were overall satisfied with their job. The perceptions of the 'ground level' prison officers reveal that there is space for improvement in the work setting, both at institution and policy level. Future studies should focus on perceptions of other categories of prison officers

Keywords: Prison officers, work-life, Correctional officers, Rehabilitation officers, Perceptions

\section{Introduction}

Prisons can be defined as institutions which confine individuals who have violated the laws that keep the smooth running of the larger society, against their will (Steiner, 2008). The main purposes of prisons are to punish criminals for the crimes they have committed by depriving them of their freedom, and to protect the community from people who pose a threat to public safety (Coyle, 2008).

In reality, the most important facet with regard to the prison is the human component, and the two most important groups of individuals at a prison are the inmates and the prison staff who take care of them. The type of the relationship between these two groups decides the ultimate good management of a prison (Coyle, 2009). Prison work is considered demanding. It is a known fact that working as a prison officer is a stressful occupation (Schaufeli \& Peeters, 2000). This is particularly because their work involves working with people whose freedom and liberty have been taken away. To make matters worse, many of their service recipients are likely to be mentally disturbed, suffering from addictions, and having poor social and educational skills. Some of them could also be dangerous and aggressive (Coyle, 2009). Prison officers are exposed to violence and other safety risks at rates which are higher than for workers in most other occupations (Steiner and Wooldredge, 2017). Officers working in jails which had characteristics that threatened order and security, had more inmates per officer and greater levels of inmate violence, have shown higher levels of stress (Ellison and Caudill, 2020). Prison officers also have a relatively high risk of experiencing victimization at work (Steiner and Wooldredge, 2017). 
'Prison guard' is considered as a job category which is involved in 'people-work' (Maslach, 1993). Literature on human services work (Hasenfeld, 1983) emphasizes that working with mal-functioning clients in 'people-changing' service category carries the highest workload, into which category prison staff falls. The inmates are kept in prison against their will, and thus they are distinct from other service recipients who approach the employees themselves to get their service. Providing a quality service to this special category of service recipients is a remarkably difficult task, taking into consideration the difficulty in getting their cooperation to provide services and rehabilitation. According to Coyle (2009), staff working at this sort of a prison setting is compelled to work in an enclosed and isolated environment, which can convert them to be 'narrow and inflexible' long-term. Further, he believes that prison staff is expected to perform a custodial, as well as a reformative role in their job, but are considered at a lower status than the others who work in the criminal justice field. According to Brower (2013), a well-established threat to the wellness of correctional officers is the stress they encounter as a result of their occupation. Ellison and Caudill (2020) have found that unreasonable workloads, perceptions of insufficient staff, role problems, less control or autonomy, a lack of support at work or home, and exposure to violence were associated with greater stress among officers working in jails. It is identified that the heavy workloads could limit the amount of mutual support provided by colleagues (Kinman et al., 2017). Multiple and unpredictable occupational risk factors such as violence, unsupportive colleagues and management, poor prison conditions, and shift work have resulted in the occupational stress among correctional officers to be insidious and chronic (Jessiman-Perreault et al., 2021).

Prison inmates are required to be provided correctional and rehabilitation services during their stay. The Department of Prisons of Sri Lanka functions under the vision of social reintegration of inmates as good citizens through rehabilitation. Their mission mentions about creating good relationships between prison officers and inmates to achieve the objectives of custody, care and corrections. Further, it emphasizes on improving job satisfaction of the officers and building positive attitudes among them, as well as regulating the welfare of the inmates (http://www.prisons.gov.lk/indexenglish.html).

In Sri Lankan, prisons placed throughout the country are managed and supervised by the central organization known as the Prison Headquarters (Department of Prisons, 2020). At the time of data collection, there were three closed prisons for convicted prisoners, where they are held normally under maximum security conditions. Remand prisons are closed Prisons reserved for remand prisoners, and there were nineteen remand prisons situated throughout the country in 2017. In addition to these, there are two open prison camps without perimeter walls, where selected prisoners are held under minimum security conditions. There are nine functioning work camps in Sri Lanka which also have no perimeter walls, and short-term or medium-term offenders are held there under minimum security conditions. There are two correctional centers plus a training school for youthful offenders, who are between the age of 16 and 22 years. A drug rehabilitation centre is also established, where inmates with drug related offences are held and rehabilitated. Further, there are 22 functioning lock-ups around the country where prisoners are held for short periods of time (Department of Prisons Sri Lanka, 2016).

Separate job categories are defined for the correction and rehabilitation of the inmates in Sri Lanka, where the uniformed prison guards, prison sergeants and jailors are mainly involved in the security and correctional activities, while the non-uniformed rehabilitation officers are mainly involved in the rehabilitation activities of the inmates (Department of Prisons, 2016). The combination of these two job categories has been designed for giving a holistic approach to the care of inmates while they are in prison. The correctional officers mainly focus on the security and supervision of the inmates, with a minor role in their training and rehabilitation, while the rehabilitation officers play a major role in training and rehabilitation. Correctional officers, while giving special emphasis on duties related to correction and security of the inmates, are also involved in registration of new entrants, escorting prisoners to courts and supervision during 'party' (various industrial and other activities) work (Personal communication, Superintendent of Prisons - Rehabilitation, 05 August 2016). The duties assigned to them are in accordance with the Prisons ordinance 1877 of Sri Lanka Prison Ordinance. It provides for prison subsidiary legislation, departmental standing orders and circulars. The Ordinance has been amended several times in accordance with the timely requirements (Department of Prisons, 2020). The role of the rehabilitation officers mainly focuses on reintegrating prison inmates to the society as good citizens through providing rehabilitation during prison life. In both job categories, except for the in-charge level officers, the others are directly and significantly in contact with the inmates, usually at a daily basis. The correctional officers who are most frequently in association with the inmates are the prison guards. They come in to contact with the prisoners on a daily basis, during their routine activities at work. 
Prison sergeants and jailors are mainly involved in in- charge level duties, except on special circumstances. By the end of 2015, there were altogether only 4131 prison guards working in prisons in Sri Lanka (Department of Prisons Sri Lanka, 2016). However, the cadre for male and female prison guards for Sri Lankan prisons was 4447 and 594, respectively, which implied unfilled cadres. Prison Rehabilitation Officers, who were earlier called Welfare Officers, are a category of non-uniformed staff attached to the Department of Prisons of Sri Lanka, who serve both convicted and remand prisoners. As at the beginning of 2016, there was a cadre for 147 Rehabilitation Officers in the Department of Prisons, out of which 112 were filled by the end of 2015. According to statistics as at the end of 2015, out of the recommended cadre, only $81.9 \%$ of prison guards and $76.2 \%$ of rehabilitation officers were working, reflecting that nearly one fifth of the cadre is not filled (Department of Prisons Sri Lanka, 2016). In Sri Lanka, most of the prison institutions are functioning with a severe shortage of staff (Dharmadasa, n.d.). It has been discussed in many forums in the prison setup at the policy making level, but still the issue is not rectified. The workload becomes the responsibility of the remaining officers, resulting in them becoming overloaded with work, making it unable for them to take leave even for an important event (Personal communication, Superintendent of Prisons Rehabilitation, 5 August, 2016).

In Sri Lanka, the service provision in the prison setting has been designed in such a way, that the services of two categories of staff have been blended in order to provide the basic services to the inmates (Personal Communication, Superintendent of Prisons - Rehabilitation, 5 August 2016). Being the lowest rank in the stepwise hierarchy of correctional officers, the prison guards shoulder the main component of duties related to providing security to the inmates while they are inside the prison, as well as when they are being escorted to courts for judicial hearings. They are the category of uniformed staff which comes in to contact with the inmates most frequently, at a regular basis during their routine duties. The higher ranks of prison correctional officers, including prison sergeants, jailors, chief jailors and superintendents of prisons, are involved more in supervisory and in-charge duties, while occasionally involved in activities which bring them into close contact with the inmates. Rehabilitation officers are also having very frequent encounters with the inmates during performing their duties, as they are involved in providing welfare facilities for the inmates. They provide services such as organizing welfare activities for the inmates and seeing whether they are being carried out successfully, promoting health among the inmates, coordinating and collaborating with the families of inmates, arranging home leave and looking in to issues arising among the inmates and finding solutions for them. Inmates look to them for their social issues, just as they would look to correctional officers with their legal issues (Personal communication, Superintendent of Prisons - Rehabilitation, 5 August, 2016).

As the rehabilitation of inmates is a crucial aspect with respect to the services provided in prison, even emphasized in the vision statement of the Department of Prisons as social integration of inmates as good citizens through rehabilitation', the quality of service rendered by the rehabilitation officers, as well as the correctional officers who are involved in correctional duties which goes hand in hand with it, has to be at a high standard for it to be successful.

This article aims to describe the perceptions of prison correctional and rehabilitation officers working on direct contact with the inmates, with regard to their work and personal life. The information in this article was collected with the intention of identifying the main personal and work-life components among them, as a prerequisite for assessing their burnout and how these factors contribute to that (will be published in a separate article).

\section{Materials and Methods}

All correctional officers (prison guards) and rehabilitation officers working in Sri Lankan prisons fulfilling the eligibility criteria were taken as the study population. The study was conducted in 32 selected prison institutions in Sri Lanka in 2017, including three closed prisons, nine remand prisons, five work camps, one open prison camp, one correctional centre for youth offenders, training school for youth offenders, rehabilitation centre for drug abuser inmates, and eleven lock-ups, to collect data of correctional officers. Some of the prisons were purposively selected while the others were randomly selected, depending upon the importance placed on information to be collected from prison officers of certain institutions. All the rehabilitation officers working in the Department of Prisons who were eligible for participating were also invited, since the number was comparatively smaller compared to the number of correctional officers. Prison officers who have been working as correctional officers and rehabilitation officers in the Sri Lankan prison setting for more than six months duration were included, while those who did not have direct and 
frequent contact with the inmates, or were on maternity leave or other long-term leave at the time of data collection, or had a diagnosis of a mental disorder at the time of the study, or couldn't read and write in Sinhala language (confirmed as a very small number prior to the study, since it's the most commonly used language in Sri Lanka), were excluded.

Table 1 Numbers of correctional officers planned to be selected from each type of prisons.

\begin{tabular}{lcc}
\hline Stratum & $\begin{array}{c}\text { Number of } \\
\text { correctional officers } \\
\text { in the stratum }\end{array}$ & $\begin{array}{c}\text { Number of } \\
\text { correctional officers } \\
\text { needed }\end{array}$ \\
\hline Closed Prisons & 909 & 645 \\
\hline Remand Prisons & 900 & 638 \\
\hline Work Camps & 196 & 139 \\
\hline Open prison Camps & 76 & 54 \\
\hline Facilities for Youth Offenders and drug abuser & 96 & 68 \\
inmates & 231 & 164 \\
\hline Lock-ups & $\mathbf{2 4 0 8}$ & $\mathbf{1 7 0 8}$ \\
\hline Total & &
\end{tabular}

One thousand seven hundred and eight was calculated as the sample size for the correctional officers, according to the Lwanga and Lemeshow's (1991) statistical formula. Multi-stage stratified sampling method was used as the sampling method for the selection of correctional officers for the study. The sample was stratified by the different categories of prisons in Sri Lanka, resulting in six strata. These strata were closed prisons, remand prisons, work camps, open prison camps, facilities for youthful offenders and drug abuser inmates, and lock-ups. The number of correctional officers selected from each stratum was proportionate to the total sample of correctional officers from the selected prisons in each stratum, at the beginning of data collection. Once the number to be selected from the stratum (each prison category) was decided, it was divided among the selected prisons of each prison category, probability proportionate to the sample size of the number of correctional officers in each of those prisons. After the number to be selected from each prison was decided, the individuals to be selected for the study were selected randomly using random number generators from numbered lists of the correctional officers in each of the selected prisons. The details of the numbers of correctional officers selected from each type of prisons are depicted in table 1.

A self-administered questionnaire containing close-ended questions was developed to assess the information on perceptions of the prison officers, focusing on the literature available on personal and work-related correlates of burnout. A thorough literature search was conducted using web-based search engines and theses on studies carried out on burnout, and information was gathered through unstructured in-depth interviews held with individuals related to the prison. These personnel included high rank prison officials involved in rehabilitation and administrative posts in the prison, public health experts collaborating with prison staff during their work, and a psychiatrist providing health services to the prison inmates. These individuals were able to provide valuable information on the work-life of the correctional and rehabilitation officers. Following the literature search and extraction of information through in-depth interviews, a list of variables to be included in the questionnaire were identified.

The questionnaire included information related to the basic socio-demographic and socio-economic characteristics. Questions on personal life included information on children, chronic illnesses, smoking and alcohol habits, income, presence of disabled individuals needing long- term care in the family and their satisfaction on various factors related to support they received from the spouse/ partner / family members, income, living conditions and the appreciation received for the work done at home and at work. Satisfaction was assessed using a five-point Likert scale. Feeling of being overburdened by housework and family-work conflict were also assessed. Information related to work-life was gathered through questions based on the years of service, permanency of the post, main duties, number of work hours per week, number of hours spent with inmates, travelling to work, shift duty, using of an official weapon, taking leave, welfare services at work and work environment. Further, as other elements related to work-life, work overload, variety and autonomy at work, role ambiguity, role conflict, underutilization of skills, 
relationships at work with inmates, their families, colleagues, superiors and external authorities, job security, career prospects, social status and views of different people about the job, salary and increments, promotions, work-family conflict and job satisfaction were also assessed. Five-point Likert scales were used for many of the questions.

The developed questionnaire was presented to a panel of five experts including a psychiatrist, a psychologist, a sociologist, a public health expert and a high rank prison official, to assess the face validity, content validity and the consensual validity of the questionnaire. They assessed each question for its relevancy in assessing correlates of burnout among prison officers, appropriateness of the wording used and the acceptability to the local context. Necessary modifications were done following their inputs. The questionnaire was translated to Sinhala language, and was back translated to English by two different bilingual experts, in order to ensure that the meanings of the original English questions were retained. The translated Sinhala version of the questionnaire was pre-tested among ten correctional officers and two rehabilitation officers working in the Prison Headquarters, who were well experienced in the job by working in prisons across the country and were in regular contact with the inmates. A few necessary modifications were made following the interviews.

The principal investigator (NW) and two trained study assistants were involved in the data collection. They visited each prison on a pre-specified date/s to collect data from the correctional officers, and visited an in-service training programme held for all the rehabilitation officers, to collect data from them. Prior administrative clearance and approval for data collection were taken from the Department of Prisons to collect data from the prison officers. At all times, the participants were explained about the study, and that they had the liberty to refrain from participating. An information sheet was provided to each of them, and adequate time was given to read it before consenting to the study. If the individual consented to participating, written consent was obtained. Instructions for completing the questionnaire were clearly mentioned, and they were also explained the instructions prior to administering the questionnaire. The participants were encouraged to ask any questions that arose while filling the questionnaire, to which the principal investigator and the study assistants answered in a uniform manner. All the collected questionnaires were collected on the same day of administration and were ensured of their completeness by the study assistants, as well as by the principal investigator at collection. All the questionnaires were collected by the principal investigator at the end of the day, and they were kept under lock and key, to ensure confidentiality. The Prison headquarters and the selected prison institutions provided their fullest coordination and support for the study, and it was evident that the selected participants were enthusiastic in completing the questionnaire.

Data entry and analysis for the study were done using the computer package 'Statistical Package for Social Sciences (SPSS) 23.0 version'. Percentages were calculated for each of the options given for the questions. Perceptions of correctional and rehabilitation officers were taken together in calculating the percentages, since the two groups were considered together as the occupational group having first line contact with the inmates. The basic socio-demographic characteristics were sub-grouped according to the occupational groups to give an overview of the study sample.

\section{Results and Discussion}

Going along with the vision and mission statements of the Department of Prisons of Sri Lanka, both correctional as well as rehabilitation and welfare services need to be provided to the inmates. The rehabilitation and welfare facilities, aiming at proper social reintegration once the inmates are released from prison, are intended to be performed by the Rehabilitation officers, while the duties related to custody, corrections and security of the inmates are bestowed upon the correctional officers, starting from the rank of prison guards.

One thousand six hundred and eighty-three correctional officers and 120 rehabilitation officers provided completed questionnaires in the study, bringing the response rates to $98.53 \%$ and $100 \%$ for the two categories of officers, respectively. This high response rate was achieved owing to the committed coordination of the higher authorities at the Department of Prisons, and the enthusiastic attitude of the participants towards the study, because this sort of a research was conducted for the first time among them. The calculated sample size for correctional officers covered more than forty percent of the total prison guards in Sri Lankan prisons. All eligible prison rehabilitation officers in the country were also included in the sample. All categories of prisons existent in Sri Lanka were represented in the current study, since the sampling was carried out taking these categories as the strata. Both correctional and rehabilitation officers were included in the sample due to the harmonized nature of their duties and 
roles in providing routine services for the inmates. Including all types of prison institutions in the study enabled to get an overall picture of the perceptions of the 'ground level' prison officers in the country.

The basic socio-demographic characteristics of the study participants are described in table 2. The majority of the study participants (85.9\%) were between 25 years and 54 years of age. The mean age of the sample of prison officers was 39.1 years (S.E. = 0.23). Previous studies conducted on burnout among prison officers have also shown closely similar mean ages of the participants (Gitau, 2013; Campos et al., 2016). The sample showed a high male representation $(88 \%)$, going in line with the sex distribution of prison officers in the Department of prisons where most of the officers are male. Many of the participants were currently married (80.6\%). Around ten percent of the participants were diploma or degree holders.

Table 2 Basic socio-demographic characteristics of the study participants

\begin{tabular}{|c|c|c|c|}
\hline $\begin{array}{c}\text { Socio- } \\
\text { demographic } \\
\text { characteristic }\end{array}$ & $\begin{array}{c}\text { Correctional } \\
\text { Officers } \\
\text { Number } \\
(\%)\end{array}$ & $\begin{array}{l}\text { Rehabilitation } \\
\text { Officers } \\
\text { Number (\%) }\end{array}$ & $\begin{array}{c}\text { Total Study } \\
\text { Participants } \\
\text { Number } \\
(\%)\end{array}$ \\
\hline $\begin{array}{l}\text { Age in completed } \\
\text { years }\end{array}$ & $(n=1683)$ & $(n=120)$ & $(n=1803)$ \\
\hline $18-24$ & $97(5.8)$ & $3(2.5)$ & $100(7.5)$ \\
\hline $25-34$ & $583(34.6)$ & $22(18.3)$ & $605(33.6)$ \\
\hline $35-44$ & $495(29.4)$ & $56(46.7)$ & $551(30.6)$ \\
\hline $45-54$ & $362(21.5)$ & $30(25.0)$ & $392(21.7)$ \\
\hline 55 and above & $146(8.7)$ & $9(7.5)$ & $155(8.6)$ \\
\hline Sex & $(n=1683)$ & $(n=120)$ & $(n=1803)$ \\
\hline Male & $1488(88.4)$ & $98(81.7)$ & $1586(88.0)$ \\
\hline Female & $195(11.6)$ & $22(18.3)$ & $217(12.0)$ \\
\hline Marital Status & $(n=1683)$ & $(n=120)$ & $(n=1803)$ \\
\hline Unmarried & $315(18.7)$ & $12(10.0)$ & $327(18.1)$ \\
\hline Currently Married & $1346(80.0)$ & $106(88.4)$ & $1452(80.6)$ \\
\hline Cohabiting & $2(0.1)$ & $0(0.0)$ & $2(0.1)$ \\
\hline Separated or Divorced & $13(0.8)$ & $1(0.8)$ & $14(0.8)$ \\
\hline Widow/Widower & $7(0.4)$ & $1(0.8)$ & $8(0.4)$ \\
\hline $\begin{array}{l}\text { Highest Educational } \\
\text { Qualification }\end{array}$ & $(n=1683)$ & $(n=120)$ & $(n=1803)$ \\
\hline $\begin{array}{l}\text { Ordinary Levels or } \\
\text { below }\end{array}$ & $46(2.7)$ & $0(0.0)$ & $46(2.6)$ \\
\hline Passed Ordinary Levels & $182(10.8)$ & $6(5.8)$ & $189(10.4)$ \\
\hline $\begin{array}{l}\text { Studied for Advanced } \\
\text { Levels }\end{array}$ & $474(28.2)$ & $12(10.0)$ & $486(27.0)$ \\
\hline Passed Advanced Levels & 839 (49.9) & $58(48.4)$ & $897(49.8)$ \\
\hline Diploma Holder & $89(5.3)$ & $27(22.5)$ & $116(6.4)$ \\
\hline Degree Holder & $53(3.1)$ & $16(13.3)$ & $69(3.8)$ \\
\hline
\end{tabular}

Excluding those who were unmarried, majority of the study participants $(87.3 \%)$ had children. Out of them, around two thirds $(66.1 \%)$ had two or more children. Just above ten percent of the participants $(11.5 \%)$ were taking care of a long-term disabled person at the time of data collection, where almost seventy percent of those personnel were parents or in-laws of the participants. Most of the participants were having a total monthly family income of 20,000 to 60,000 Sri Lankan Rupees. Around twenty per cent of the participants were current smokers, whereas half of the participants have smoked during their lifetime. Just about five percent of the current smokers were smoking ten or more cigarettes daily. Sixty-two per cent of the participants mentioned that they were consuming alcohol, but most of them were doing so either sometimes or rarely. Presence of a chronic disease was self-reported by 665 (36.9\%) of the participants, while $254(14.1 \%)$ were suffering from diabetes, $180(10.0 \%)$ from hypertension, 69 (3.8\%) from bronchial asthma, 69 (3.8\%) from heart diseases, $168(9.3 \%)$ from arthritis, $113(6.3 \%)$ from varicose veins and $112(6.2 \%)$ from other chronic diseases. Twenty-nine participants (1.6\%) were feeling burdened by housework almost daily, while $232(12.9 \%)$ felt that their family life was adversely affecting their work-life. This concept defines the demands and time devoted to, and the stress created by the family interfering with the job 
(Netemeyer, Boles \& McMurrian, 1996). Family-work conflict originates in the family setting, such as activities related to child-care, spousal duties, gender roles expectations etc., and has an impact on work life including absenteeism, being late to work, leaving the job and fatigue etc. (Shaukat, 2017). Personal life characteristics of the participants are detailed in table 3.

Table 3 Information and perceptions related to personal life of the study participants

\begin{tabular}{|c|c|}
\hline Presence of children $(n=1$ & \\
\hline Yes & $1289(87.3 \%)$ \\
\hline No & $187(12.7 \%)$ \\
\hline Number of children $(n=12$ & \\
\hline 1 & $437(33.9 \%)$ \\
\hline 2 & $641(49.7 \%)$ \\
\hline 3 or more & $211(16.4 \%)$ \\
\hline Presence of a long-term d & \\
\hline Yes & $208(11.5 \%)$ \\
\hline No & $1595(88.5 \%)$ \\
\hline Relationship with the disa & \\
\hline Parent/ In-law & $145(69.7 \%)$ \\
\hline Child & $18(8.7 \%)$ \\
\hline Other & $45(21.6 \%)$ \\
\hline Total monthly family inco & \\
\hline$<20,000$ & $52(2.9 \%)$ \\
\hline $20,000-60,000$ & $1417(78.6 \%)$ \\
\hline $60,001-100,000$ & $306(17.0 \%)$ \\
\hline$>100,000$ & $28(1.5 \%)$ \\
\hline Current smoking $(n=1803$ & \\
\hline Yes & $368(20.4 \%)$ \\
\hline No & $1435(79.6 \%)$ \\
\hline Current smoking habit ( $\mathrm{n}=$ & \\
\hline Daily, $>10$ cigarettes a day & $17(4.6 \%)$ \\
\hline Daily, <=10 cigarettes a day & $104(28.3 \%)$ \\
\hline More than 3 days a week & $64(17.4 \%)$ \\
\hline Sometimes & $102(27.7 \%)$ \\
\hline Rarely & $81(22.0 \%)$ \\
\hline Ever smoking $(n=1803)$ & \\
\hline Yes & $918(50.9 \%)$ \\
\hline No & $885(49.1 \%)$ \\
\hline Current alcohol consumpt & \\
\hline Yes & $1118(62.0 \%)$ \\
\hline No & $685(38.0 \%)$ \\
\hline Current alcohol habit $(\mathbf{n}=$ & \\
\hline Daily & $6(0.5 \%)$ \\
\hline$>3$ days a week & $47(4.2 \%)$ \\
\hline 1-3 days a week & $87(7.8 \%)$ \\
\hline Seldom/ Rarely & $978(87.5 \%)$ \\
\hline Presence of chronic diseas & \\
\hline Diabetes & $254(14.1 \%)$ \\
\hline Hypertension & $180(10.0 \%)$ \\
\hline Bronchial asthma & $69(3.8 \%)$ \\
\hline Heart diseases & $69(3.8 \%)$ \\
\hline Arthritis & $168(9.3 \%)$ \\
\hline Varicose veins & $113(6.3 \%)$ \\
\hline
\end{tabular}


Other

Presence of any chronic disease $(n=1803)$ $665(36.9 \%)$

Feeling burdened by housework $(n=1803)$

Never

Rarely

$537(29.8 \%)$

Sometimes

$662(36.7 \%)$

Often

$472(26.2 \%)$

Very often

$25(1.4 \%)$

Almost daily

$78(4.3 \%)$

Perception of family life adversely affecting work-life $(n=1803)$

Yes

$29(1.6 \%)$

No

$232(12.9 \%)$

Don't know

$1332(73.9 \%)$

Note. $* 1 \mathrm{SLR}=0.007 \mathrm{USD}$ at the time of data collection

Satisfaction of the participants regarding entities related to their personal life were enquired using a fivepoint Likert scale on satisfaction (see table 4). Many of the study participants were satisfied with the support received from the spouse/ partner/ family members in housework and taking care of children $(67.3 \%$ and $85.9 \%$, respectively). A relatively lower proportion was satisfied with the support received from them for taking care of disabled family members (47.1\%). Sixty-four per cent of the participants felt that they were satisfied with the support from spouse/ partner/ family members in career development. Around ten per cent were not satisfied with their family income. Almost two thirds (63.5\%) of the participants were satisfied with the physical environment and conditions of their living place, and the people they were associating with, while just above two thirds (68.4\%) were satisfied with the appreciation and complements from family members for efforts made by them in housework and their profession. A considerable proportion of the participants had neutral views for the above aspects.

Table 4 Perceptions of the study participants on their satisfaction about aspects related to personal life

\begin{tabular}{|c|c|c|c|c|c|}
\hline Entity & $\begin{array}{l}\text { Highly } \\
\text { satisfied }\end{array}$ & $\begin{array}{l}\text { Somewhat } \\
\text { satisfied }\end{array}$ & Neutral & $\begin{array}{l}\text { Somewhat } \\
\text { unsatisfied }\end{array}$ & $\begin{array}{l}\text { Highly } \\
\text { unsatisfied }\end{array}$ \\
\hline $\begin{array}{l}\text { Support received from the spouse/ } \\
\text { partner/ family members in housework } \\
(\mathrm{n}=1803)\end{array}$ & $\begin{array}{l}1031 \\
(57.2 \%)\end{array}$ & $\begin{array}{l}183 \\
(10.1 \%)\end{array}$ & $\begin{array}{l}540 \\
(30.0 \%)\end{array}$ & $\begin{array}{l}26 \\
(1.4 \%)\end{array}$ & $\begin{array}{l}23 \\
(1.3 \%)\end{array}$ \\
\hline $\begin{array}{l}\text { support received from the spouse/ } \\
\text { partner/ family members in taking care of } \\
\text { children }(n=1289)\end{array}$ & $\begin{array}{l}1011 \\
(78.4 \%)\end{array}$ & $\begin{array}{l}96 \\
(7.5 \%)\end{array}$ & $\begin{array}{l}144 \\
(11.2 \%)\end{array}$ & $\begin{array}{l}12 \\
(0.9 \%)\end{array}$ & $\begin{array}{l}26 \\
(2.0 \%)\end{array}$ \\
\hline $\begin{array}{l}\text { Support received from the spouse/ } \\
\text { partner/ family members in taking care of } \\
\text { disabled family members }(n=208)\end{array}$ & $\begin{array}{l}72 \\
(34.6 \%)\end{array}$ & $\begin{array}{l}26 \\
(12.5 \%)\end{array}$ & $\begin{array}{l}102 \\
(49.1 \%)\end{array}$ & $\begin{array}{l}4 \\
(1.9 \%)\end{array}$ & $\begin{array}{l}4 \\
(1.9 \%)\end{array}$ \\
\hline $\begin{array}{l}\text { Support from spouse/ partner/ family } \\
\text { members in career development } \\
(n=1803)\end{array}$ & $\begin{array}{l}929 \\
(51.5 \%)\end{array}$ & $\begin{array}{l}226 \\
(12.5 \%)\end{array}$ & $\begin{array}{l}593 \\
(32.9 \%)\end{array}$ & $\begin{array}{l}28 \\
(1.6 \%)\end{array}$ & $\begin{array}{l}27 \\
(1.5 \%)\end{array}$ \\
\hline Total family income $(n=1803)$ & $\begin{array}{l}216 \\
(12.0 \%)\end{array}$ & $\begin{array}{l}468 \\
(26.0 \%)\end{array}$ & $\begin{array}{l}932 \\
(51.7 \%)\end{array}$ & $\begin{array}{l}145 \\
(8.0 \%)\end{array}$ & $\begin{array}{l}42 \\
(2.3 \%)\end{array}$ \\
\hline $\begin{array}{l}\text { Physical environment and conditions of } \\
\text { the living place, and people associating } \\
\text { with ( } n=1803)\end{array}$ & 602 & $\begin{array}{l}542 \\
(30.1 \%)\end{array}$ & $\begin{array}{l}575 \\
(31.9 \%)\end{array}$ & $\begin{array}{l}58 \\
(3.2 \%)\end{array}$ & $\begin{array}{l}26 \\
(1.4 \%)\end{array}$ \\
\hline $\begin{array}{l}\text { Appreciation and complements from } \\
\text { family members for efforts made in }\end{array}$ & $\begin{array}{l}761 \\
(42.2 \%)\end{array}$ & $\begin{array}{l}472 \\
(26.2 \%)\end{array}$ & $\begin{array}{l}508 \\
(28.2 \%)\end{array}$ & $\begin{array}{l}35 \\
(1.9 \%)\end{array}$ & $\begin{array}{l}27 \\
(1.5 \%)\end{array}$ \\
\hline
\end{tabular}

housework and profession $(\mathrm{n}=1803)$

Table 5 depicts some of the work-related information of the sample. A total of 662 correctional and rehabilitation officers from closed prisons participated in the study, accounting to around one third of the sample, while approximately another one third of the sample consisted of officers working in remand prisons (693, 38.4\%). Around three fourths of the sample had work experience between five to twenty years. Only 68 had worked for 6 months to one year. The majority (89.4\%) of the sample had been made permanent in their job. Just above one fourth of the participants (26.4\%) were able to reach their workplace from home within ten minutes, while for around ten percent, it took more than two hours. The main duty declared by around forty percent of the sample was both 
providing security and escorting inmates to courts, while another $20.2 \%$ mentioned their main duty as providing security to inmates in wards or cells, and $15.4 \%$ mentioned escorting inmates to courts as their main duty. Another 149 and 153 mentioned providing security to inmates during 'party' work (vocational training and other routine work in the prison) and providing rehabilitation services to inmates, respectively. One thousand participants (55.5\%) mentioned that they need to possess an official weapon during work. Carrying the weapon had to be done usually during escorting inmates to courts, and quite a number of correctional officers were involved in that activity at a regular basis. With regard to the self-declaration of the number of hours of duty per week, the majority (77.5\%) were working $40-70$ hours. Another $18.4 \%$ declared that they worked for more than 70 hours a week. Almost three fourths $(1324,73.4 \%)$ of the respondents were engaged in shift work at the time of data collection, and $88.7 \%$ of them $(n=1174)$ were expected to work on nights shifts. Out of those who had to work on night shifts, nearly half (45.6\%) declared that they worked ten or more night shifts a month. Around four fifths of those who worked in shifts $(79.7 \%)$ mentioned that they were expected to work double shifts, indicating that they had to work two shifts in a row. Out of them, more than half (55.1\%) experienced this once or twice a month or at a lesser frequency.

Table 5 Work-related information of the prison officers

\section{Work-related characteristic}

\begin{tabular}{|c|c|}
\hline \multicolumn{2}{|l|}{ Category of Prison $(n=1803)$} \\
\hline Closed Prisons & $662(36.7 \%)$ \\
\hline Remand Prisons & $693(38.4 \%)$ \\
\hline Work Camps & $154(8.5 \%)$ \\
\hline Open Prison Camps & $59(3.3 \%)$ \\
\hline CCYO and DRC & $75(4.2 \%)$ \\
\hline Lock-ups & $160(8.9 \%)$ \\
\hline \multicolumn{2}{|l|}{ Years of Work Experience $(n=1803)$} \\
\hline$<1$ year & $68(3.8 \%)$ \\
\hline 1 to 5 years & $387(21.5 \%)$ \\
\hline$>5$ to 10 years & $466(25.7 \%)$ \\
\hline$>10$ to 20 years & $497(27.6 \%)$ \\
\hline$>20$ to 30 years & $239(13.3 \%)$ \\
\hline$>30$ years & $146(8.1 \%)$ \\
\hline \multicolumn{2}{|l|}{ Made Permanent in the Job $(n=1803)$} \\
\hline Yes & $1617(89.7 \%)$ \\
\hline No & $186(10.3 \%)$ \\
\hline \multicolumn{2}{|l|}{ Time Taken to Reach for Work $(n=1803)$} \\
\hline$<10$ minutes & $476(26.4 \%)$ \\
\hline $10-30$ minutes & $311(17.2 \%)$ \\
\hline$>30$ min -1 hour & $455(25.2 \%)$ \\
\hline$>1$ hour -2 hours & $382(21.2 \%)$ \\
\hline$>2$ hours & $179(9.9 \%)$ \\
\hline \multicolumn{2}{|l|}{ Main Duty $(n=1803)$} \\
\hline Providing security to inmates in wards/cells & $364(20.2 \%)$ \\
\hline Providing security to inmates during escorting them to courts & $277(15.4 \%)$ \\
\hline Providing security to inmates during party work & $149(8.3 \%)$ \\
\hline Registration of inmates & $78(4.3 \%)$ \\
\hline Providing rehabilitation services to inmates & $153(8.5 \%)$ \\
\hline Both providing security and escorting to courts & $782(43.4 \%)$ \\
\hline \multicolumn{2}{|l|}{ Need for Possessing an Official Weapon $(n=1803)$} \\
\hline Yes & $1000(55.5 \%)$ \\
\hline No & $803(44.5 \%)$ \\
\hline \multicolumn{2}{|l|}{ Hours of Duty per Week $(n=1803)$} \\
\hline$<40$ hours & $74(4.1 \%)$ \\
\hline
\end{tabular}




\begin{tabular}{lc}
\hline $40-50$ hours & $445(24.7 \%)$ \\
\hline$>50-60$ hours & $525(29.1 \%)$ \\
\hline$>60-70$ hours & $427(23.7 \%)$ \\
\hline$>70$ hours & $332(18.4 \%)$ \\
\hline $\begin{array}{l}\text { Number of Hours Spent with Inmates Per Day } \\
(\mathbf{n}=\mathbf{1 8 0 3})\end{array}$ & \\
\hline$<2$ hours & $208(11.5 \%)$ \\
\hline $2-4$ hours & $208(11.5 \%)$ \\
\hline$>4-6$ hours & $543(30.1 \%)$ \\
\hline$>6$ hours & $844(46.9 \%)$ \\
\hline Currently Doing Shift Work (n=1803) & \\
\hline Yes & $1324(73.4 \%)$ \\
\hline No & $479(26.6 \%)$ \\
\hline Expected to Do Night Shifts (n=1324) & $1174(88.7 \%)$ \\
\hline Yes & $150(11.3 \%)$ \\
\hline No & $57(4.9 \%)$ \\
\hline Number of Night Shifts Per Month (n=1174) & $315(26.8 \%)$ \\
\hline 1 & $266(22.7 \%)$ \\
\hline $2-5$ & $536(45.6 \%)$ \\
\hline $6-9$ & $1055(79.7 \%)$ \\
\hline 10 or more & $269(20.3 \%)$ \\
\hline Expected to Do Double Shifts (n=1324) & $267(25.3 \%)$ \\
\hline Yes & $314(29.8 \%)$ \\
\hline No & $180(17.1 \%)$ \\
\hline Frequency of Doing Double Shifts (n=1055) & $190(18.0 \%)$ \\
\hline Less than once a month & $104(9.8 \%)$ \\
\hline $1-2$ times a month & \\
\hline Nearly once a week & \\
\hline $2-3$ times a week & \\
\hline More than 3 times a week & \\
\hline & \\
\hline
\end{tabular}

Perceptions about work-related entities were enquired next. The perception about working in shifts was enquired from those who worked in shifts. More than half (56.6\%) of them were always comfortable with it, whereas a minority of $3.9 \%$ most of the time found it difficult to adjust to it. When enquired about taking leave, almost half (49.3\%) mentioned that they could take leave when they needed, while for around one third, it was difficult to take leave due to cover-up for duty not being available. Taking leave is an issue for the prison officers in Sri Lanka, due to the inadequacy of staff at almost every prison institution owing to the unfilled cadres. While for some, it could be easier to apply and take leave, for some others in institutions or duties with higher deficiencies in the number of staff, taking leave has become a great mental burden (Personal communication). Many were in the idea that the eligible number of leave was adequate $(n=1180,65.4 \%)$. Only a minority $(3.9 \%)$ mentioned that the welfare facilities were excellent, but more than half $(58.4 \%)$ agreed that they were good or satisfactory. It is a common complain of the prison officers that even though welfare facilities for inmates is taken as an issue of high priority, such emphasis is not given for the welfare facilities provided for the prison staff. Almost three fourths of the participants (73.7\%) were in the perception that there was inadequate staff in the units they worked. With regard to the workload, $61.4 \%$ were in the impression that the amount of work to be done was tolerable, but another $22.1 \%$ believed that they were overloaded with work. When the reasons were enquired from those who believed that they were overloaded with work, there were mixed perceptions, with the most common perceptions being the need to complete a large amount of work within a short time (31.9\%) and the need to perform overtime and extra shifts due to inadequate staff $(22.4 \%)$. According to statistics as at the end of 2015 , out of the recommended cadre, only $81.9 \%$ of prison guards and $76.2 \%$ of rehabilitation officers were working, reflecting that nearly one fifth of the cadre is not filled (Department of Prisons Sri Lanka, 2016). This could be the main reason for the increased workload for the existing officers. Around seventy-five per cent of the participants always had a clear idea about the duties they were expected to perform, while the rest were unsure of what was expected from them at least sometimes. Only around ten per cent declared that they never had to perform conflicting roles in the job, while the others experienced it at different 
frequencies at work. Around three fourths (76.6\%) of the participants felt insecure about their job at least sometimes, while $4.9 \%$ had no idea about it. Around one third (34.4\%) believed that career development was available only to those who had special skills. Around forty-seven per cent agreed that there was good support from the institutions for extra learning, while an almost similar proportion believed that the support was inadequate. A minority of $6.5 \%$ believed that there was no opportunity for extra learning at all. Almost one fourth (23.2\%) of those who had to carry an official weapon at work, did not like it. Around one fourth of the participants found their salary to be adequate and believed that it was adequate in relation to the work done by them, while the rest believed that the salary they received was inadequate, and that they deserved a higher salary for the work they carried out. Only about one fourth $(24.2 \%)$ of those who found the question relevant agreed that the increments were adequate as well as given in a timely manner, while $17.5 \%$ of those who found the question relevant believed that they did not receive the promotion they deserved. When the perceptions on the social status received for the job were enquired, around thirty per cent agreed that there was little or no respect for their job from the society. The majority of the participants $(83.1 \%)$ were honoured to be in their job, and an almost similar percentage believed that their families thought the same. Around eighty per cent thought that the inmates respected them and their job, but a minority (7.4\%) had thoughts such as the inmates despising the prison officers and their job, and that the inmates could be thinking that they did not have any say in their occupation and thus didn't have any respect for the officers. Close to one fourth of the participants (22.9\%) believed that their work-life was adversely affecting their family life, while another $16.1 \%$ didn't have an idea about it. This work-family conflict is known to arise from the variables that are associated with the work such as job demands, job pressures, working hours, organizational culture, work-related stresses and overburden and causes conflicts in family life with difficulty to perform the roles and requirements associated with family (Shaukat, 2017). When enquired about the overall job satisfaction, it was evident that $59.2 \%$ were satisfied while $4.5 \%$ were unsatisfied, while the rest were having neutral views. See table 6 for the distribution of work-related perceptions mentioned above.

Table 6 Work-related perceptions of the prison officers

\section{Perception}

Number (\%)

\begin{tabular}{ll}
\hline Doing Shift Work (n=1324) & \\
\hline Always comfortable with it & $749(56.6 \%)$ \\
\hline Rarely find it difficult to adjust to it & $378(28.5 \%)$ \\
\hline Sometimes find it difficult to adjust to it & $146(11.0 \%)$ \\
\hline Most of the time find it difficult to adjust to it & $51(3.9 \%)$
\end{tabular}

\begin{tabular}{ll}
\hline Ability to Take Leave When Necessary $\mathbf{( n = 1 8 0 3 )}$ & \\
\hline Can take leave when needed & $889(49.3 \%)$ \\
\hline Difficult to take leave due to no cover-up & $617(34.2 \%)$ \\
\hline Cannot take leave even for an urgent need & $102(5.7 \%)$ \\
\hline Problem with taking leave due attitude of the leave approving officer & $195(10.8 \%)$ \\
\hline Eligible Number of Leave (n=1803) & $1180(65.4 \%)$ \\
\hline Adequate & $623(34.6 \%)$ \\
\hline Inadequate & \\
\hline Welfare Facilities at Work (n=1803) & $70(3.9 \%)$ \\
\hline Excellent & $441(24.4 \%)$ \\
\hline Good & $613(34.0 \%)$ \\
\hline Satisfactory & $492(27.3 \%)$ \\
\hline Poor & $187(10.4 \%)$
\end{tabular}

\begin{tabular}{ll}
\hline Adequacy of Staff in the Unit They Work $(\mathbf{n = 1 8 0 3 )}$ & \\
\hline More than adequate & $16(0.9 \%)$ \\
\hline Sufficient & $458(25.4 \%)$ \\
\hline Inadequate & $1329(73.7 \%)$
\end{tabular}




\section{Amount of Work Needed to be Done $(n=1803)$}

Under-worked

Tolerable amount of work

Overloaded with work

$298(16.5 \%)$

$1107(61.4 \%)$

$398(22.1 \%)$

\section{Reason for Feeling Overloaded with Work $(n=398)$}

Need to complete a large amount of work within a short time

$127(31.9 \%)$

Need to complete multiple tasks at the same time

$75(18.8 \%)$

Inadequate time to recover between duties

$76(19.1 \%)$

Need to perform overtime and extra shifts due to lack of staff

$89(22.4 \%)$

Need to travel long distances frequently

No specific reason

$10(2.5 \%)$

$21(5.3 \%)$

\begin{tabular}{ll}
\hline Having a Clear Idea about the Duties $(\mathbf{n = 1 8 0 3})$ & \\
\hline Always have a clear idea & $1369(75.9 \%)$ \\
\hline Sometimes unsure of what is expected & $389(21.6 \%)$ \\
\hline Most of the time unsure of what is expected & $45(2.5 \%)$
\end{tabular}

\section{Frequency of Having to Perform Conflicting Roles in the Job $(n=1803)$}

Never

Rarely

Sometimes

Often

Almost daily

$183(10.1 \%)$

$634(35.2 \%)$

$720(39.9 \%)$

$207(11.5 \%)$

$59(3.3 \%)$

\section{Job Security $(n=1803)$}

Feel very secure always

$334(18.5 \%)$

Feel unsecure sometimes

$944(52.4 \%)$

Feel unsecure most of the time

$436(24.2 \%)$

No idea

$89(4.9 \%)$

\section{Career Development $(n=1803)$}

No career prospects

$338(18.7 \%)$

Career development is only for people with special skills

$620(34.4 \%)$

Career development is available for al

$422(23.4 \%)$

Career development is blocked by institution

$423(23.5 \%)$

Perception on Extra Learning $(n=1803)$

Receive good support from the institution

$852(47.3 \%)$

Inadequate opportunity from the institution

$834(46.2 \%)$

No opportunity from the institution at all

$117(6.5 \%)$

\begin{tabular}{ll}
\hline Perception about Possessing an Official Weapon $\mathbf{( n = 1 0 0 0 )}$ & \\
\hline Feel secure & $713(71.3 \%)$ \\
\hline Feel prestigious & $55(5.5 \%)$ \\
\hline Don't like to carry it & $232(23.2 \%)$ \\
\hline Perceptions on Salary/Allowances (n=1803) & \\
\hline Adequate & $450(25.0 \%)$ \\
\hline Not adequate & $1353(75.0 \%)$ \\
\hline $\begin{array}{l}\text { Perceptions on Adequacy of Salary in Relation to the Work Done } \\
\text { (n=1803) }\end{array}$ & \\
\hline Fair for the work done & $452(25.1 \%)$ \\
\hline Deserve more for the work done & $1351(74.9 \%)$ \\
\hline Perception on Increments $(\mathrm{n}=1765)^{*}$ & \\
\hline Adequate and timely & $428(24.2 \%)$ \\
\hline Adequate but delayed & $292(16.6 \%)$ \\
\hline Inadequate but timely & $697(39.5 \%)$ \\
\hline
\end{tabular}


Inadequate and delayed

$348(19.7 \%)$

\begin{tabular}{ll}
\hline Perception on Promotions in the Job $(\mathrm{n}=1429)^{*}$ & \\
\hline Timely and fair & $604(42.3 \%)$ \\
\hline Delayed & $575(40.2 \%)$ \\
\hline Didn't receive the promotion deserved & $250(17.5 \%)$ \\
\hline Perceptions on the Social Status Received for the Job $(\mathrm{n}=1803)$ & $1113(61.7 \%)$ \\
\hline Society highly respects this job & $645(35.8 \%)$ \\
\hline Not much respect from the society & $45(2.5 \%)$ \\
\hline No respect from the society & \\
\hline Own View on the Job ( $\mathrm{n}=1803)$ & $941(52.2 \%)$ \\
\hline Much honoured & $558(30.9 \%)$ \\
\hline Somewhat honoured & $295(16.4 \%)$ \\
\hline Neither honoured nor ashamed & $8(0.4 \%)$ \\
\hline Somewhat ashamed & $1(0.1 \%)$
\end{tabular}

\begin{tabular}{ll}
\hline Perceptions on Views of the Family on the Job $(\mathrm{n}=1803)$ & \\
\hline Much honoured & $937(52.0 \%)$ \\
\hline Somewhat honoured & $543(30.1 \%)$ \\
\hline Neither honoured nor ashamed & $252(14.0 \%)$ \\
\hline Somewhat ashamed & $17(0.9 \%)$ \\
\hline Much ashamed & $3(0.2 \%)$ \\
\hline Don't know & $51(2.8 \%)$
\end{tabular}

\begin{tabular}{ll}
\hline Perception on the View of Inmates on the Job $(\mathrm{n}=1803)$ & \\
\hline They respect us and our occupation & $1427(79.1 \%)$ \\
\hline They are just scared of us, but they don't have much respect & $243(13.5 \%)$ \\
\hline $\begin{array}{l}\text { They think we have no say in our occupation, so they don't have any respect for } \\
\text { us }\end{array}$ & \\
\hline They despise us and our occupation & $45(2.5 \%)$ \\
\hline Perception on Work-life Adversely Affecting Family Life $(\mathrm{n}=1803)$ & \\
\hline Yes & $412(22.9 \%)$ \\
\hline No & $1100(61.0 \%)$ \\
\hline Don't know & $291(16.1 \%)$ \\
\hline Overall Job Satisfaction $(\mathrm{n}=1803)$ & \\
\hline Very much satisfied & $418(23.2 \%)$ \\
\hline Somewhat satisfied & $649(36.0 \%)$ \\
\hline Not satisfied nor unsatisfied & $655(36.3 \%)$ \\
\hline Somewhat unsatisfied & $62(3.4 \%)$ \\
\hline Very much unsatisfied & $19(1.1 \%)$ \\
\hline
\end{tabular}

Note. *Others found the question 'not relevant'

When the prison officers were enquired about their satisfaction about the work environment, 160 (8.9\%) were highly satisfied with the work environment with regard to it being free of threat of violence and danger, while 305 (16.9\%) were somewhat satisfied. Two hundred and forty (13.3\%) and 151 (8.4\%) participants were somewhat unsatisfied and highly unsatisfied in that aspect, respectively, whereas, more than half $(947,52.5 \%)$ had neutral views. With regard to their satisfaction on the work environment being Free of contracting communicable diseases, only $5.2 \%(n=94)$ were highly satisfied, and $11.4 \%(n=205)$ found the conditions somewhat satisfying. Neutral views were held by $41.4 \%$ of the participants $(n=747)$, whereas $374(20.8 \%)$ and $383(21.2 \%)$ were somewhat unsatisfied and highly unsatisfied, respectively. Cleanliness of the work environment was perceived by $13.5 \%(n=244)$ as highly satisfying, by $25.8 \%(n=425)$ as somewhat satisfying, by $14.5 \%(n=262)$ as somewhat unsatisfying and by $7.5 \%$ $(n=134)$ as highly unsatisfying, while $36.7 \%(n=698)$ held neutral views. Satisfaction of the participants on the odour of their working environment was also enquired, and respectively 114 (6.4\%), 285 (15.8\%), 417 (23.1\%) and 285 $(15.8 \%)$ were highly satisfied, somewhat satisfied, somewhat unsatisfied and highly unsatisfied with the condition, 
while the rest had neutral views. The ventilation of the working environment was up to their high satisfaction in $12 \%$ $(n=217)$ of the participants. Another $20.8 \%(n=375)$ found it somewhat satisfying, and $16.7 \%$ and $9.7 \%(n=299$ and 174) were somewhat unsatisfied and highly unsatisfied about it. Neutral views were held by $40.9 \%(n=738)$. Orderliness of the working environment was found to be highly satisfying to 238 (13.2\%) participants, while 88 $(4.9 \%)$ found it highly unsatisfying. Four hundred and ninety-seven $(27.6 \%)$ and $194(10.7 \%)$ found the condition to be somewhat satisfying and somewhat unsatisfying respectively, while the rest indicated a neutral attitude. When their satisfaction on the resting facilities at work were enquired, only $6.8 \%(n=122)$ found them highly satisfying. Another $19.1 \%(n=344)$ were somewhat satisfied, and 35.2\% $(n=636)$ were neither satisfied nor unsatisfied. Three hundred and seventy-one participants (20.6\%) were somewhat unsatisfied with the resting facilities, while $18.3 \%$ $(n=330)$ mentioned the facilities as highly unsatisfying.

The prison officers were enquired about the variety of the work they carried out, using five-point Likert scale type questions. One hundred and fifty-three (8.5\%) participants replied 'excellent' to getting a variety of tasks to perform, while 809 (44.9\%), 627 (34.7\%), 157 (8.7\%) and 57 (3.2\%) replied 'good', 'satisfactory', 'poor' and 'very poor' to the question, respectively. Low level of repetitiveness of work was perceived as 'excellent' by $2.3 \%(n=42)$, as 'good' by $33.9 \%(n=612)$ and as satisfactory by $46.5 \%(n=836)$, while $13.8 \%(n=249)$ and $3.5 \%(n=64)$ answered 'poor' and 'very poor' respectively, to the question. Ninety-seven (5.4\%) participants found that the occasions for creativity during work was excellent, while 424 (23.5\%) and 614 (34.1\%) found it 'good' and 'satisfactory', respectively. However, 668 participants (37\%) thought that the occasions for creativity during work was poor or very poor. Six hundred and seventy-five participants (37.4\%) were not happy with the opportunities at work to learn new things and answered 'poor' or 'very poor' to the question. The others had more favourable attitudes towards the question, mentioning 'excellent' (192, 10.6\%), 'good' (446, 24.7\%) and 'satisfactory' (490 (27.3\%). The final question under variety at work was on the opportunity for developing special abilities during work. For this question, 140 (7.8\%) mentioned 'excellent', 404 (22.4\%) mentioned 'good' and 521 (28.9\%) mentioned 'satisfactory', while $453(25.1 \%)$ thought it was 'poor' and $285(15.8 \%)$ thought it was 'very poor'.

The participants were asked whether they found their job dull and boring, to which around one third (621, $34.4 \%)$ answered as 'never'. Another 629 (34.9\%) rarely felt like that, while 484 (26.8\%) mentioned 'sometimes', and $52(2.9 \%)$ mentioned 'often'. Seventeen participants $(0.9 \%)$ felt their job to be dull and boring almost daily. With regard to autonomy at work, the perceptions of the participants on their ability to take decisions at work were assessed using three questions. When their ability to make decisions in their own job was enquired, only $6.7 \%$ $(n=120)$ graded it as 'excellent', but a larger proportion of $30.3 \%(n=546)$ and $34.1 \%(n=616)$ graded it as 'good' and 'satisfactory', respectively. However, $23.2 \%(n=419)$ found it 'poor', and 5.7\% $(n=102)$ found it 'very poor'. Next, the ability to influence the work team during work was assessed, and only $3 \%(n=54)$ thought it was 'excellent'. Others thought it was good $(452,25.1 \%)$, satisfactory $(764,42.3 \%)$, poor $(405,22.5 \%)$ or very poor $(128,7.1 \%)$. Only a minority of $0.7 \%(n=13)$ thought that their ability to influence higher department policies was excellent, and only another $9.8 \%(n=177)$ and $28.7 \%(n=518)$ thought it was at least good or satisfactory, respectively. More than half of the participants thought it was poor, where $33.8 \%(n=609)$ mentioned it as 'poor' and $27 \%(n=486)$ mentioned it as 'very poor'.

The officers receive a basic training when they first join the service, and are offered continuous or in-service training from time to time during work. The total training period for the prison correctional and rehabilitation officers is only four months of duration, and it mainly focuses on sections like rules and regulations, prison setup and prison ordinance. It was assessed how they thought these trainings were utilized during work. With regard to the utilization of their basic training, $229(12.7 \%)$ participants thought that it was excellent, $762(42.3 \%)$ thought it was good and $586(32.5 \%)$ thought it was satisfactory. Only $186(10.3 \%)$ thought it was poor, and $40(2.2 \%)$ thought the utilization was very poor. As for the continuous training, almost similar results were obtained: excellent $(305,17.8 \%)$, good $(601,35.1 \%)$, satisfactory $(593,34.6 \%)$, poor $(156,9.1 \%)$, and very poor $(59,3.4 \%)$. Following his analysis of the prison system in Sri Lanka since independence, Dharmadasa (n.d.) has stressed on the fact that there is a practical difficulty in conducting sufficient training programmes for the staff due to the shortage of staff for daily duties and the lack of financial resources. He emphasizes that the basic training they receive at the time they are recruited to the service cannot be deemed adequate at all, in terms of duration, as well as the content covered in it.

Another aspect assessed with regard to the perceptions of the participants was their relationship with superiors, colleagues and inmates. First, the general perception on the relationship with colleagues, inmates and 
superiors, as well as with families of inmates and external authorities working in collaboration with the prison, were assessed. The officers were coming into contact with the families of inmates when the families visited the inmates, and they were in contact with external authorities when special programmes, trainings and medical services were organized for the inmates as well as for the officers. Thereafter, a few questions were asked to assess the relationship with colleagues, inmates and superiors further. With regard to the general perception on relationship with colleagues, $292(16.2 \%)$ thought it was excellent, $995(55.2 \%)$ thought it was good, $485(26.8 \%)$ thought it was satisfactory and $30(1.7 \%)$ thought it was poor, while only one participant $(0.1 \%)$ thought it was very poor. Only $65(3.6 \%)$ believed that the relationship with inmates was excellent, while $706(39.2 \%)$ and $874(48.4 \%)$ believed that the relationship was good and satisfactory, respectively. One hundred and eleven (6.2\%) participants thought it was poor, and $47(2.6 \%)$ thought it was very poor. Nearly ten per cent $(167,9.3 \%)$ had the perception that their relationship with the superiors was excellent. Another 844 (46.8\%) thought it was good and $657(36.4 \%)$ thought it was satisfactory. However, $107(5.9 \%)$ thought the relationship with superiors was poor, and $28(1.6 \%)$ thought it was very poor. When the perceptions about the relationship with families of inmates was enquired, 56 (3.1\%) thought it was excellent, $619(34.3 \%)$ thought it was good and $823(45.7 \%)$ thought it was satisfactory, while the others had negative perceptions, with 191 (10.6\%) mentioning the relationship as 'poor' and 114 (6.3\%) mentioning it as 'very poor'. The relationship with external authorities working in partnership with the prison was found to be excellent to $149(8.3 \%)$, good to $792(43.9 \%)$ and satisfactory to $668(37 \%)$. However, $153(8.5 \%)$ thought it was poor while the remaining $41(2.3 \%)$ thought it was very poor.

When the relationship with colleagues was further assessed, it was identified that $7.7 \%$ of the participants $(n=139)$ thought that getting support from their colleagues showed incompetence. Seven hundred and two participants $(38.9 \%)$ believed that their job expected them to have individual responsibility rather than team responsibility. Interestingly, $22.7 \%(n=410)$ of the officers were in the perception that their job didn't expect them to interact with their colleagues regularly. The relationship with superiors was further assessed using six aspects. Seven hundred and ninety participants (43.8\%) thought that there was lack of communication, while 611 (33.9\%) thought that there was inadequate support. Inadequate feedback was identified by 645 (35.8\%) participants. Seven percent $(n=126)$ of the participants thought that there was unfair harassment to them and $6.3 \%$ believed that they were unfairly discriminated. Five hundred and seventeen participants $(28.7 \%)$ thought that their views were not being considered by the superiors. Perceptions about inmates was assessed using two questions. The first question assessed how they mostly thought about the inmates and were asked to select out of five pre-specified options given. Out of the participants, $126(7 \%)$ thought they were not dangerous, $130(7.2 \%)$ thought that though they were dangerous, they would not be harming the officers and $105(5.8 \%)$ thought that would harm the officers at any given moment. The most frequent options chosen were 'They also have good qualities. If you treat them well, they will behave well', chosen by 736 (40.8\%) participants, and 'You can never predict them', chosen by 706 (39.2\%) participants. The second question enquired whether they thought they received assistance from inmates in performing duties in the job, to which 1212 (67.2\%) agreed.

The results included in this article were gathered as a pre-requisite for a larger study which was carried out to assess the burnout of Sri Lankan prison officers, in which these perceptions were tested as possible correlates. However, the perceptions of the prison officers presented in this paper itself yields a wealth of information about them, which could be well-utilized in taking important decisions for their betterment, particularly in view of improving their work conditions, both at the institution as well as at the policy level.

\section{Study limitations and guidance for future research}

This study considered the perceptions of the 'ground-level' prison officers in Sri Lanka only, and therefore, the perceptions cannot be generalized to all the prison officers in Sri Lanka. However, conducting the study in prison institutions across the country and including all types of prison institutions in the study gives strength to the study in generalizing the study results to the 'ground level' prison guards and rehabilitation officers in Sri Lanka. The study assessed the perceptions using a questionnaire with close-ended questions, developed following an extensive literature search and consultation with experts related to the field. However, following a qualitative approach in the form of focus group discussions or in-depth interviews as the main study design, or prior to the quantitative approach could have yielded further deep-seated perceptions unique to prison officers in Sri Lanka. Future research should 
aim at assessing the perceptions of other categories of prison officers not included in the current study, and also consider the use of a qualitative study design at least as part of the study in assessing perceptions.

\section{Conclusions}

Prison officers who participated in this study had mixed perceptions with regard to their personal life as well as their work-life. When their work-life was considered, some were feeling overloaded with work, some had issues with regard to their relationship with their colleagues and superiors as well as with the inmates, and they were sometimes unsatisfied with the work environment and the welfare facilities. In their personal life, they were sometimes overburdened with housework and had varying levels of satisfaction with household conditions. The information gathered in the study, with special regard to their work-life, could be very useful in understanding their perceptions on the issues and difficulties they face during work. Thus, this information could be valuably utilized in making possible institutional and policy level changes in the work setting, to create a more favourable work environment for the prison officers. This would be beneficial not only for the prison officers but getting better work conditions and more satisfaction at work would in turn contribute to provision of a better service to the inmates under their care, especially with regard to rehabilitation.

\section{References}

Brower, J., (2013). Correctional officer wellness and safety literature review. Washington DC, USA: Office of Justice Programs Diagnostic Centre.

Campos, J.A.D.B., Schneider, V., Bonafe, F.S.S., Oliveira, R.V., \& Maroco, J., (2016). Burnout Syndrome and alcohol consumption in prison employees. Revista Brasileira de Epidemiologia (Brazilian Journal of Epidemiology), 19(1), 205-216.

Coyle, A., (2009). A Human Rights approach to prison management: handbook for prison staff, London, United Kingdom: International Centre for prison studies.

Coyle, A., (2008). Understanding prisons. Paper presented at the Prison Fellowship New Zealand 25th Anniversary Conference, New Zealand. Retrieved November 19, 2016 from http://www.pfnz.org.nz/Site\%20PDF/2008Conference/PFNZ_Understanding_Prisons. Pdf

Department of Prisons. (2016). Prison Statistics of Sri Lanka. Colombo, Sri Lanka: Author.

Department of Prisons. (2020). Prison Reforms Five Year Plan (2021-2025): A right based correctional system for a safer society. Colombo, Sri Lanka: Author.

Dharmadasa, H. G. (n.d.). A general overview of the prison system in Sri Lanka since independence. Retrieved January 03, 2017 from https://www.academia.edu/6073176/A GENERAL OVERVIEW OF THE PRISON SYSTEM IN SRI LANKA \%20SINCE INDEPENDENCE

Ellison, L.M., \& Caudill, J.W. (2020). Working on local time: Testing the job-demand-control-support model of stress with jail officers. Journal of Criminal Justice, 70, 101717.

Gitau, C.W. (2013). Prevalence of burnout among prison officers at Kamiti Command (Masters Thesis, University of $\begin{array}{lllll}\text { Nairobi, Kenya) } \quad \text { Retrieved January } 2017 \text { from } & \text { 15 }\end{array}$ http://erepository.uonbi.ac.ke/bitstream/handle/11295/58835/Gitau_PrevalenceOfBurnoutmongPrisonOffic ers.pdf?sequence $=3$

Hasenfeld, Y. (1983). Human service organizations. Englewood Cliffs, New Jersey: Prentice Hall.

Jessiman-Perreault, G., Smith, P. M., \& Gignac, M.A.M., (2021). Why Are Workplace Social Support Programs Not Improving the Mental Health of Canadian Correctional Officers? An Examination of the Theoretical Concepts Underpinning Support (Review). International Journal of Environmental Research and Public Health, 18, 2665. https://doi.org/10.3390/ijerph18052665

Kinman, G., Clements, A.J., \& Hart, J., (2017). Job demands, resources and mental health in UK prison officers. Occupational Medicine, 67, 456-460.

Lwanga, S.K., \& Lemeshow, S., (1991). Sample size determination in health studies: A practical manual. Geneva, Switzerland: World Health Organization. 
Maslach, C., (1993). Burnout: A Multidimensional Perspective. In W. B. Schaufeli, C. Maslach, \& T. Marek (Eds.), Professional burnout: Recent developments in theory and research (pp. 19-32). Washington DC, USA: Taylor \& Francis.

Netemeyer, R.G., Boles, J.S., \& McCurrian, R. (1996). Development and Validation of Work-Family Conflict and Family-Work Conflict Scales. Journal of Applied Psychology, 81(4), 400-410.

Prisons Ordinance $1878 \quad$ (SL) S.8 $\quad$ (SL.). Retrieved October 25, 2016, from http://hrlibrary.umn.edu/research/srilanka/statutes/Prisons_Ordinance.pdf

Schaufeli, W.B., \& Peeters, M.C.W., (2000). Job stress and burnout among correctional officers: A literature review. International Journal of Stress Management, 7(1), 19-48.

Schaufeli, W.B., Maslach, C., \& Marek, T. (Eds.). (2017). Professional burnout: Recent developments in theory and research. (pp. 19-32). Washington DC, USA: Taylor \& Francis.

Shaukat, M. (2017). A Study on Work-Family and Family-Work Conflict Experiences ofFemale Teachers of University of the Punjab Lahore. Unpublished thesis, University of the Punjab Lahore.

Steiner, B. (2008). Maintaining prison order: Understanding causes of inmate misconduct within and across Ohio Correctional Facilities. Unpublished dissertation, University of Cincinnati.

Steiner, B., \& Wooldredge, J. (2017). Individual and Environmental Influences on Prison Officer Safety. Justice Quarterly, 34(2), 324-349. http://dx.doi.org/10.1080/07418825.2016.1164883

Does this article screened for similarity: YES

Ethics Approval: Ethics approval for the study was obtained from the Faculty of Medicine, University of Kelaniya, Sri Lanka.

Authors Contribution: Nimali Wijegoonewardene: Conceptualization, Methodology, Formal analysis, Writing - Original Draft, Writing - Review \& Editing; Janaki Vidanapathirana: Conceptualization, Methodology, Supervision, Writing - Review \& Editing

Funding: This work was supported by the Component II of the Second Health Sector Development Project of the Ministry of Health, Nutrition and Indigenous Medicine - Sri Lanka (Grant number: SHSDP/RG/2016/29). The funding source had no involvement in the in the study design, collection, analysis and interpretation of data, writing of the report or the decision to submit the article for publication.

Conflict of Interest: The authors have no conflicts of interest to declare that they are relevant to the content of this article.

\section{About The License}

(C) The author(s) 2021. The text of this article is open access and licensed under a Creative Commons Attribution 4.0 International License

\section{Cite this Article}

Nimali Wijegoonewardene and Janaki Vidanapathirana, Personal and Work-Life Perceptions of Sri Lankan Prison Correctional and Rehabilitation Officers, Asian Journal of Interdisciplinary Research, 4(3) (2021) 1-17. https://doi.org/10.34256/aijr2131 